Man and Nature

L'homme et la nature

\title{
Hume: Justice as Property
}

\section{Nathan Brett}

Volume 6, 1987

URI : https://id.erudit.org/iderudit/1011870ar

DOI : https://doi.org/10.7202/1011870ar

Aller au sommaire du numéro

Éditeur(s)

Canadian Society for Eighteenth-Century Studies / Société canadienne d'étude du dix-huitième siècle

ISSN

0824-3298 (imprimé)

1927-8810 (numérique)

Découvrir la revue

Citer cet article

Brett, N. (1987). Hume: Justice as Property. Man and Nature / L'homme et la nature, 6, 55-72. https://doi.org/10.7202/1011870ar

Copyright $@$ Canadian Society for Eighteenth-Century Studies / Société canadienne d'étude du dix-huitième siècle, 1987
Ce document est protégé par la loi sur le droit d'auteur. L'utilisation des services d'Érudit (y compris la reproduction) est assujettie à sa politique d'utilisation que vous pouvez consulter en ligne.

https://apropos.erudit.org/fr/usagers/politique-dutilisation/
Cet article est diffusé et préservé par Érudit.

Érudit est un consortium interuniversitaire sans but lucratif composé de l’Université de Montréal, l'Université Laval et l'Université du Québec à Montréal. Il a pour mission la promotion et la valorisation de la recherche. https://www.erudit.org/fr/ 


\section{HUME: JUSTICE AS PROPERTY}

Though what Hume calls justice is an artificial virtue, justice properly so called is not.

J. Harrison, Hume's Theory of Justice ${ }^{1}$

In the Treatise Hume claims to show that justice is an artificial virtue. Rawls clearly thinks that Hume has made a contribution to the analysis of justice; he claims tha: Hume's account of the circumstances of justice is superior to his own. ${ }^{2}$ But I (like Harrison in the quote above) have never been quite sure that Hume managed to say a word about the subject. The relevant sections of the Treatise ${ }^{3}$ and the Enquiry 4 are primarily discussions of property, which is given a basis in convention, rather than status as a natural right. These chapters contain, as well, discussions of promise keeping, chastity, and modesty, which are also argued to be intelligible only by reference to underlying conventions which we have collectively invented and collectively sustain. These arguments are interesting; but, again, what do these virtues have to do with justice? Is promiscuity a form of injustice?

I will argue (in passing) that these virtues are connected with justice in Hume's account because they are connected with property. But the primary task of this paper is to articulate the connections between justice and property that Hume's account presupposes. After considering the view of both Locke and Hume that this is a logical connection, I proceed to defend two claims. (1) On Hume's account, property ex- 
ists where things are distributed by reference to moral attitudes which have a basis in convention. These conventions provide the criteria in terms of which we determine whether a transaction is just. Apart from their instrumental value, there is no foundation for the rational criticism of these conventions themselves. Thus, as long as these conventions work to produce stability, following the rules of property is being just. (2) This conclusion seems unpalatable because we suppose that property rules can themselves be criticized utilizing the concept of justice. What has not been generally perceived, however, is that the Humean conventions which are constitutive of property have impartiality and reciprocity built into them. It is this that allows Hume to capture much of what we ordinarily mean by justice.

I

Humean Property: In both the Treatise and Enquiry we find Hume comparing divisions and transfers of property with superstitious behaviour. ${ }^{5}$ Compare any two objects such that one is your property, the other is not. How do they differ? In their physical properties they need not differ at all. I need not be in physical possession of what is mine. No physical characteristic and no relational property "discoverable to the senses" is a basis of distinctions of property. Yet the world is largely divided into "touchable" and "untouchable" objects; invisible barriers keep us out and off and away from most of the things in our respective worlds. We are so accustomed to this, of course, that its mysteriousness goes unnoticed most of the time. Hume directs us to the resemblance between property and the objects of religious taboos:

A fowl on Thursday is lawful food, on Friday abominable: Eggs in this house and in this diocese, are permitted during Lent; a hundred paces farther, to eat them is a damnable sin. ( $E$, p. 198)

I may lawfully nourish myself from this tree; be fruit of another of the same species, ten paces off, it is criminal for me to touch. (E, p. 199)

When we think about property transactions in the abstract they seem equally mysterious:

Had I worn this apparel an hour ago I would have merited the severest 
punishment; but a man, by pronouncing a few magical syllables, has now rendered it fit for my use and service. (E, p. 199)

What is the difference between things and property, or between property and "possessions," to use one of Hume's ways of marking the distinction?

The property of an object, when taken for something real, without any reference to morality, or to the sentiments of the mind, is a quality perfectly insensible and even inconceivable; nor can we form any notion of either its stability or [transfer] translation. ( $T$, p. 515$)$

Hume's claim in this section is that the difference between possessions and property is the difference between things which are physically within my control and those that are "morally" (or legally) within my control. The point, in Humean terms, is that the difference between mere objects and property is a difference in "sentiment," a difference in attitude toward a particular person's use (etc.) of that thing. But, this is also what distinguishes between objects considered in themselves from the same things as the objects of taboo or superstition. No description of the properties of these objects can provide an understanding of our attitudes. To do this we must interpose conventions. Thus, property distinctions are products of artifice, and conformity to these conventions is an "artificial" virtue, radically unlike such "natural virtues" as compassion.

The difference between the conventions or rules generating superstition and those generating property, according to Hume, lies entirely in their respective utilities. The former is "frivolous, useless, and burdensome; the latter is absolutely requisite to the well-being of mankind and society" (E, p. 199). Though this is not a sufficient account of the difference between property and superstition, of course, it accounts for the difference in their value. Uselessness makes it a vice to be superstitious. Utility makes it a virtue to adhere to the rules of property.

By the end of the first part of Book III of the Treatise Hume believes he has established that moral distinctions are not based on reason. Reason of course has a role in the discovery of means to ends and in the discernment of factual differences between the objects of evaluation, but reason itself is indifferent to the various options which may be open to us, whereas moral or any other evaluative distinctions cannot be matters of indifference. Hume takes the central problem regarding moral distinctions we utilize to be an explanatory one. We must ask 
"Why any action or sentiment upon the general view or survey gives a certain satisfaction or uneasiness?" ( $T$, p. 475). Here Hume is attempting to stick to the empirical method to which both he and Locke were committed, and which Locke largely abandoned when he turned his attention to the moral and political realm. It will not do, given Hume's method, to build one's account of morality (or of the justification of government) on natural rights or laws. We do not discover our rights or obligations as sensible properties or relations of things and persons. What we do discover, on reflection, are certain attitudes that we have; and the comparison of these may allow us to discern some general principles that shape our evaluations. Vice and virtue, good and bad action are inseparable from that which gives a "certain satisfaction or uneasiness". To understand our morality is to understand why contemplation of (or witnessing) various actions gives rise to the feelings (of pleasure and pain) through which these distinctions are made.

Hume's pursuit of the question of why actions and character traits affect us as they do leads him to the division between natural and artificial virtues. Some of our moral values depend upon basic human responses which we can notice in ourselves but which we cannot further explain. We do in fact (generally) squirm with "uneasiness" at the sight of another in great distress; correspondingly, we naturally approve of benevolent acts aimed at the relief of such distress (other things being equal). If we had no such (sympathetic) response to distress, the acts aimed at its relief would be a matter of indifference. Hume spends a good deal of time illustrating the ways in which sympathy operates (the way in which an idea of pain in another becomes an impression of pain in oneself, for example). He does not attempt to explain why we react sympathetically. This he takes to be one of the basic, general principles of human nature on which he relies in accounting for other moral phenomena.

Now, we have seen already that our attitude toward possessions is not subject to any account similar to our attitude toward the relief of suffering, not subject to an account based directly upon dispositions which are natural to us as human beings. ${ }^{6}$ In fact, our sympathy will often lead us to have moral qualms about the ways in which possessions are divided among human beings -- when we notice, for example, that there is no correlation between human needs and the possessions necessary to satisfy these needs, when we see a judge restoring goods to a miser or to some "profligate debauchee" $(T, \mathrm{p}$. 482). Taken individually, the attitudes which are constitutive of property can be in direct conflict not only with self-interest, but also with the extended interest that we take in other persons. Nonethe- 
less, we should not suppose that property has nothing to do with selfinterest, or that the attitudes toward possession which it involves are not moral ones. We need to know what things to rely upon in satisfying our needs; and we generally believe that there is something morally wrong with theft. Since there is no "natural" correlation between persons and things, we have had to invent ways of dividing things up in the process of interacting with each other.

There is no property except where persons interact with each other in uniform ways. There is no property apart from the sentiments through which we collectively endorse these patterns of interaction. Even the fact that a person has through his or her labour modified some material to create something useful cannot by itself yield any "natural right " to property in the object (as Locke had claimed). ${ }^{7}$ To make something is to cause changes in the physical properties of an object; and this alone cannot bring about any moral change in the relation between person and object. To infer that it does is clearly an attempt to derive an 'ought' from an 'is. ${ }^{8}$ Of course, there may be excellent reasons to adopt this convention regarding acquisition -- i.e., it may be a useful and stabilizing pattern of interaction. But so too are there good reasons for treating valueless pieces of paper as if they were precious, in conducting transactions with each other. Each of these is artificial in the sense that the values involved cannot be understood in terms of any direct connection between the interests and needs (and hence sentiments) of persons and the values which objects have in satisfying those interests.

Virtue and Justice: The whole of the discussion of Part II falls under the heading of justice, which Hume claims to prove an artificial virtue. The previous section of this paper was designed to indicate what significance that has. The "uneasiness" that is felt in contemplating taking someone's property is, in its origin, quite unlike that which we feel when we contemplate his or her bodily harm. Our attitude would be just like a superstitious response to an object of taboo, if it were not for the utility of the co-ordinated behaviour that (generally) follows from this attitude. This behaviour manifests the artificial virtue of justice.

A. Non-sequitur: But here one might accuse Hume of a non-sequitur. How did we get from the artificiality of property distinctions to the 
artificiality of justice? Should we simply assume that questions of justice pertain wholly or primarily to property? When I compare my own intuitions about justice with Hume's I find myself baffled. I would not have supposed that there is any necessary connection between following property conventions and behaving justly. We may judge that theft is wrong; but whether it is unjust appears to be a separable issue. We can even imagine conditions in which justice is re-established by stealing. That justice is simply a matter of following rules and in that sense giving to each person what is owed, is a view disposed of by Plato's Socrates with one counter-example. ${ }^{9}$ But Hume, who was familiar enough with Plato,${ }^{10}$ works with the assumption that justice is the virtue of following rules of possession -- as if this were too obvious to require either proof or comment.

Actually, the long chapter on "justice and injustice" does not deal entirely with virtue connected with property. There are also discussions of promises, fidelity, and chastity. But here I find my intuitions concerning justice (or 'justice', at least) even more strained. Breaking one's promises might be a matter of doing injustice, just as stealing could be. But this need not be the case. It may well be wrong to break one's promise to meet a friend for lunch; but it is not obviously unjust. On the other hand, that either infidelity or being unchaste is a "kind of injustice" (T, p. 572) is a thought that would never have occurred to me. It would probably not have occurred to Hume if he were not looking at the matter through the eyes of his theory. Had a student written that prostitutes were being "unjust" in practicing their trade, I would have scribbled "wrong word" without a second thought. Should we suppose that English has changed since the time of $\mathrm{Hu}$ me's writing? The (longer) Oxford English Dictionary yields no evidence in support of this. Thus, the virtues which Hume takes up that are not (or not obviously, see below) connected with property, seem to take us even further from the subject. We have no reason as yet, then, for dropping the charge that it is a non-sequitur for Hume to claim that he has shown justice to be an artificial virtue.

B. Begging the Question: One might wonder if Hume is tacitly using the term 'justice' in a way that confines it to those values which can only be understood as attitudes shaped by convention. It is this that is claimed as the common denominator of those virtues that are taken up in the chapter on justice and injustice. It is this basis in convention that makes it impossible to understand these virtues as natural responses, and hence makes them artificial virtues. But, of course, this is a most uncharitable interpretation of Hume's way of delimiting the scope of judgements of justice and injustice, since it completely 
undermines the major argument of this part of his discussion in the Treatise. Hume purports to be arguing that justice is an artificial virtue. Virtues are artificial when they cannot be understood directly in terms of attitudes which are natural to us as human beings, that is, where they can only be understood when our sentiments are taken to be shaped by convention. But if he is using 'justice' in such a way that it designates only those values which have a conventional basis, he is exploring a tautology that his own usage has created.

C. Property, Promises and Promiscuity: I do not think it is possible to completely extricate Hume from either the complaint of non-sequitur or circularity. It is clear, however, that there is a greater degree of continuity to the discussion of justice than is revealed by simply listing the topics that Hume takes up. It appears, in particular, that all of the discussion does revolve around what Hume takes to be property, provided at least that we take property relations in an extended sense.

(i) Hume's central belief in these discussions is that it is "absolutely necessary" for co-operative social existence that there be divisions between "mine" and "yours." The discussion of promises is not separable from Hume's general theory of property. The subject arises pursuant to the problem of how order is to be maintained in the transfer of possessions. Co-operation requires that there be some device through which orderly transfers can sometimes be made, and by means of which we can co-operate in the exchange of labour. Hence, the account is extended to accommodate the problem of exchange of labour. Hume's account revolves around the need to create and maintain a climate of stable expectations, one in which individuals can know who and what they can rely upon in satisfying their needs and (other) interests. This problem is solved by persons entering into contractual agreements. But contracting and promising cannot themselves be the product of any explicit agreements, for this would presuppose what is to be explained. Thus Hume has recourse to the idea of an unexpressed convention in his account of the expressed agreements through which property and labour are exchanged.

(ii) The virtues of chastity and modesty also concern the division of property. Just as it is necessary to "partition" external objects to avoid useless and destructive forms of interaction, so it is necessary in Hume's view to divide persons into those which are mine and not mine: my wife, your husband, and, in particular, his child. There is no hope of understanding the virtues of modesty, chastity, or fidelity simply as natural responses. To take one example, why should intimacies toward two persons who appear to be equal in sexual attractiveness be subject to opposite attitudes? The one is "mine", the other is not. 
The actual social world is one that makes property out of persons. Here, as elsewhere, this conventional relation among persons connects with a natural one. Parents are naturally disposed to provide for the children which they cause to exist; but conventions governing sexual behaviour by forbidding promiscuity and making virtues of modesty, chastity, and fidelity are necessary in order that male parents establish what children are theirs.

The conventions that Hume discerns and defends in relation to this epistemic need (knowing who fathered whom) have made him the object of various egalitarian critiques, notably those of feminists. Most notorious is Hume's contention that fidelity and chastity are of far greater importance in women than in men (because of the difference in ease with which maternity and paternity are established). Now, obviously there are assumptions in Hume's treatment of this subject that deserve examination and criticism; but that is a task separate from my own and one that has been undertaken quite successfully elsewhere. ${ }^{11}$ What I want to draw attention to in Hume's account is this: We have seen already that Hume's theory of property makes room for conflict between the attitudes which are constitutive of our property and those which are products of sympathy, of our capacity to experience the world as if we were another person. Thus, we would be led to expect, given Hume's account, that we will have moral attitudes related to and supportive of the conventions through which we divide persons into property. But, we should anticipate as well that we will have moral reservations about this system, just as we have regarding the general rules through which we allocate needed commodities.

III

The Ideas of Property and Justice: The supposed connection between justice and following these general rules of property is not directly examined by Hume. He appears to have held that this is a logical relation. This was also Locke's view, though its significance in Locke's moral and political theory is dramatically different. In a passage of the Essay where he is illustrating the sort of reasoning that yields demonstrative certainty Locke says

"Where there is no property there is no injustice" is a proposition as certain as any in Euclid: for the idea of property being a right to anything, and the idea to which the name injustice is given being the invasion or violation of that 
right, it is evident that ... I can as certainly know this proposition to be true as that a triangle has three angles equal to two right ones. (Essay, IV,iii, 18)

This example is one that Hume repeats almost exactly in the Enquiry (Book I) though his intention is to mark this as merely a truth about words, quite unlike the sort of demonstrative knowledge available in mathematics.

That the square of the hypotenuse is equal to the square of the two other sides, cannot be known, let the terms be ever so exactly defined, without a train of reasoning and enquiry. But to convince us that where there is no property there can be no injustice, it is only necessary to define the terms and explain injustice to be a violation of property. This proposition is, indeed, nothing but a more imperfect definition ( $E$, p. 131).

There is an interesting puzzle here. When Locke actually turned to the discussion of property (in his Second Treatise) he made no attempt to construct the Euclidian system of truths which he points to here. In fact, the concepts of justice play no important role in his discussion of natural rights and property. Hume, on the other hand, who claims that the connection between justice and property to be merely a matter of words ("it is only necessary to define the terms") makes a great deal of his discussion of justice depend upon this supposed logical connection between 'justice' and 'property'. Moreover, Hume does not follow Locke in allowing the concept of property to expand to cover a wide range of normative relations. He does not introduce, for example, Locke's central conception that individuals have property in their own persons. ${ }^{12}$

The theoretical disagreement between Hume and Locke regarding property is so profound that much of Hume's discussion of the subject can usefully be read as an attack on Locke's central views. For Locke, the all encompassing right to property is a natural one; Hume's more restricted conception makes property entirely artificial..$^{13}$ Locke's property is ultimately grounded on the authority of God and the relation between God and the individual human being; Hume, as we have seen, makes a comparison between property distinctions and religious taboos; but far from finding a foundation here, Hume writes this aspect off as "superstition". Locke took his primary task to be that of showing how we arrived at private ownership from a condition in which all things are held in common, without any appeal to an agreement "among the commoners." Hume, on the other hand, sees convention, 
and hence (tacit) agreement among interacting persons as precisely what is generative of property relations.

Perhaps the most significant contrast, however, can be gleaned from what may seem to be a trivial difference between the above quotations from Locke and Hume. Whereas Locke commits himself to the view that injustice is always "an invasion or violation of right", Hume speaks simply of a "violation of property" and makes no mention of rights in characterizing the connection between justice and property. Locke commits himself to the following argument:

(a) the idea of property is the idea of "a right to anything."

(b) the idea of injustice is the idea of the "invasion or violation of a right."

(c) Therefore, if there were no property there could be no rights and without rights there could be no injustice.

Here we are given the primary claims which we would have to consider in a critical examination of the Lockean account. One could argue that this account of rights is too restrictive, that there are rights (e.g., to life or to some level of welfare) which cannot be construed as property rights. Again, one could argue that there are forms of injustice which do not involve violations of rights (e.g. where a parent gives radically unequal gifts to equally well behaved children). But the argument as a whole does not exist in Hume's account because he finds no room for its middle term, for the premise concerning rights. ${ }^{14} \mathrm{Hume}$, as we have seen, can find no basis for the idea of a natural right. He only utilizes the term 'right' in a way that connects with express or tacit rules (or conventions) which govern the interaction of persons. Nonetheless, he accepts the Lockean conclusion that property and justice are logically related. It is obvious, however, that neither Locke nor Hume is simply reporting a connection between the terms 'property' and 'justice' which was embedded in the ordinary language of their time. ${ }^{15}$ Both are in fact elaborating conceptual connections which reflect and depend upon aspects of their respective normative theories. Hume cannot rely upon the conception of a basic natural right in linking justice with property. We must therefore ask what premises in Hume's account do generate this connection. It is to this speculative task that I now turn. 
Justice as Property: Taking Hume's "imperfect" definition to be at least partly stipulative, then, I want to ask what philosophical motivation he has in linking questions of justice and questions of property. There are two sorts of connection that I shall briefly consider. The first works from the very general claim that justice is a virtue of distributions; the second explores a type of reciprocity which is built into Hume's concept of convention.

A. Distributive Value: Let's suppose that, despite the problems discovered in our initial review of Hume's examples of justice, his conception of justice is not far different from our own, or from that which Rawls attempted to explicate in this century. Justice is a value (or virtue) that pertains to the allocation, or distribution of things which are themselves valued (either positively or negatively). ${ }^{16}$ Let me attempt an outline of Hume's account based on this assumption:

1) Questions of justice concern the value of allocations, of the distribution of what is itself of value. (For simplicity I will omit consideration of burdens, services, and persons here.)

2) In any society the system of institution of property is that which supplies answers to the primary questions of allocation or distribution of that which is separately valued.

3) Property is not a descriptive but a "moral" concept; that is persons interacting under a system of property are maintaining the separation (and orderly transfer) of possessions through a shared set of attitudes. It is only because they mutually value a certain way of allocating things that property exists.

4) Thus, for Hume, property, which is a "moral" (a normative) concept is, like justice, the idea of a valued distribution, or, in his words, "partition" of goods.

Before continuing, let me comment briefly on this conclusion. We are likely to balk at the identification of justice with property because systems of property can themselves be assessed as either just or unjust. This, of course, was one of my primary reasons for doubting that Hume had proved anything about the artificiality of justice in showing that property is based on convention. Any conceptual analysis which entails that whatever system of property we have is necessarily 
just appears perverse, appears to require that we beg the most important questions of justice.

We must keep these doubts in mind. Ultimately, we may want to reject the Humean principles that lead him to this identification. But it is important not to lose sight of the feature of property that Hume has discerned here. Property is not simply the stuff of the world that meets certain needs. Conceiving of anything as property is thinking about it as "partitioned" by our shared values. As we have seen, property has no "objective" existence apart from the "impressions of satisfaction and uneasiness" that constitute our values. Thus, if we raise the question of the justice of property relations themselves, we raise the second order question of what attitude to take toward the moral attitudes which are constitutive of property. Let's consider this from Hume's point of view.

Reflective assessment of one's values is a matter of considering their rationality or examining them in relation to the "calm passions." (i) Moral distinctions, Hume has argued, are not based on reason; nor are they subject to rational criticism. But this way of putting the matter is misleading. Wherever something is valued as a means our attitude toward it depends upon a factual claim which it may or may not be rational to believe. It is on this basis that some conventions are rejected as "superstition." (ii) Moral distinctions are based on sentiments which we express to one another. Through a process that allows us to achieve agreement in attitude by omitting from consideration the particulars of our situation, we may subject our values to a further type of assessment. (See T, p. 603.) On Hume's view, neither of these types of assessment will lead us to reject the conventions through which we (successfully) partition possessions. Thus,

5) No distribution of goods is inherently more rational than any other.

6) Our natural sentiments (including those produced by sympathy) do not generate agreement regarding the allocation of goods. But calm reflection on the matter leads us to endorse the conventions which permit us to reach agreement.

7) These conventions can only be assessed instrumentally, in terms of their ability to produce the co-operation which human existence requires. Some systems of allocation are better suited than others to serve our need to cooperate.

On Hume's view there is no a priori answer to the question of how 
things ought to be allocated. If it is no more rational (where reason is separated from the passions) to prefer the pricking of one's little finger to the destruction of the whole world than vice versa, it is also no more rational to prefer, say, an equal distribution of goods to the assignment of everything to one person. But this says only that reason, considered independently of our interests, cannot discover or select among our ends. Given certain interests, some courses of action (or patterns of restraint) are more rational than others because they are means to the satisfaction of these interests. In this sense, justice is a product of rationality, for we have discovered the need to co-operate in order to achieve what we desire, and we have discovered the need for stability of possession if we are to co-operate.

Conventions regarding the allocation of goods can be assessed in terms of their contribution to this (intermediate) goal of co-operation. Hume does just this. He considers the proposals that we should agree on an equal distribution, that distribution should be based on need, and that merit ("extensive virtue") be the criterion in terms of which goods are distributed. Each of these is dismissed (too quickly perhaps) on grounds that it will fail to produce the stability of possession which co-operation depends upon. ${ }^{17}$

I find myself repelled by this treatment of justice as a merely instrumental value; but at the same time I find myself captivated by $\mathrm{Hu}-$ me's skepticism. Particular patterns of distribution seem inherently unjust and subject to criticism not based on the results which they produce in the long run for those who are subject to them. But, most of us are aware not only of the possibility of producing whole systems based on allocation by need, or by reference to effort, or by appeal to equality. We are also aware of the difficulty of showing that one of these systems is rationally superior to the other. Most of us are aware as well of the way in which the standards of need, merit, and equality can be brought into conflict with each other in particular decisions regarding the allocation of, for example, jobs or positions in medical schools. Few could be confident, upon reflection, that there is always a rationally superior resolution of such dilemmas. Perhaps no one should be confident. In Hume we find a sustained attempt to accommodate this inability to base justice on rationality itself. The upshot is that we do not have any basis for the critical appraisal of the institutions through which allocations are made -- other than the ability of those institutions to provide a stable basis for co-operation. Hume's collapse of questions of justice into questions of property can be taken as a manifestation of his principled skepticism about the possibility of 
a rational critique of those conventions through which successful allocations are made.

B. Convention and Reciprocity: So far I have tried to illuminate $\mathrm{Hu}-$ me's virtual identification of questions of justice with those of property by characterizing justice as a value relating to distribution of things and property as things allocated or "partitioned" by a shared set of values. I have deliberately ignored the ways in which property is a creature of law, the ways in which these shared values come to be reflected in (and shaped by) statutes and precedents. This I have done because Hume is not among the theorists who regard property as originally generated by law. He would have found this thesis as plausible as we would find the hypothesis that natural languages were brought into existence by ancient grammarians. Legislators (and judges) articulate and give prudential force to conventions that already are operative in a community. They also make changes in the system of conventions that they discover, when, for example, it turns out that existing rules are insufficient to settle a dispute over possession. ${ }^{18}$ (In this respect, too, there is an analogy with grammarians, who have also played a role in the evolution of the natural languages that they study.) On Hume's view, the conventions which generate property are one of the conditions necessary for the development of law. I shall end by considering how these conventions may themselves be related to justice.

Something -- quite a bit in fact -- is missing from the account of justice in terms of a valued distribution of goods. Even if we are ultimately forced to concede that there is no entirely rational basis for selecting among patterns or criteria of distribution, some systems (such as that of Apartheid) remain repugnant to our sense of justice because they do not treat persons impartially. If Hume's treatment of justice makes no connection with impartiality, I think it really would not be an account of "justice properly so called." But it is clear that Hume takes impartiality to be a part of the concepts of justice and property that he has discovered to be underwritten by convention. ${ }^{19}$ This is partly because the virtue of justice that he has articulated is a disposition to stick to rules in the face of one's inclinations or sympathies, and even in the face of conflicting utilities. There is a sense in which persons are being treated impartially when general rules are followed, rather than being bent to accommodate such particular factors as these.

But it is notorious that formalism, or impartiality in the application of rules, is not sufficient for justice. The most hideously unjust rules of a South Africa can be applied without exceptions which accommodate bias, sympathy, or utility -- and without justice. Obviously this 
is true. But the question which we must face here is whether the type of convention which is the foundation of Hume's account is subject to the same complaint.

Consider the famous passage where Hume illustrates what he means by a convention using the example of the co-operative effort of two persons manning oars on either side of a rowboat. ${ }^{20}$

Two men, who pull the oars of a boat do so by an agreement or convention, though they have never given promises to each other.

The actions of each ... have a reference to those of the other, and are performed on the supposition, that something is to be performed on the part of the other.

[Similarly,] I observe that it will be in my interest to leave another in possession of his goods, provided he will act in the same manner with regard to me. He is sensible of a like interest in the regulation of his conduct. ( $T, \mathrm{p}$. 490; second italics mine).

What Hume claims to be illustrating in these passages is the type of activity through which individuals "from their early education in society" $(T, 489)$ acquire the conventional forms of interaction which are the basis of the "ideas of justice and injustice" ( $T$, p.490). The conventions Hume is analyzing here are not articulated rules or agreements. It is through their actions that the individuals in the boat (and in the society of which it is an analogue) "express to one another" ... "a sense of common interest." Each is "expressing" a co-operative interest through the very act that accomplishes a shared purpose. It is important that the action of each agent be taken as an example to the others: "every single act is performed in the expectation that others are to perform the like" ( $T$, p. 498). According to Hume the coordination of possessions in society begins (historically, and in the development of the individual person) as a similarly informal process of interaction. If one of the oarsmen fails to act in conformity with the other neither will get where he wants to be. If one person attempts to take what another has in his (physical) possession he cannot expect to rely on the items within his own possession. It is from this imitative form of co-ordination that individuals acquire a sense of justice. The conventions embedded in their interactions are the prototypes from which the more sophisticated conceptions of justice and equity arise as systems of positive law are developed.

Now, while there is plenty of room for partiality and hence injustice 
in even a strict application of official, articulated rules, it is far from obvious that this is possible in relation to the tacit conventions which Hume has described. The actions of each participant serve partly as examples to the other participants. They co-operate in this type of conventional behaviour by imitating each other, and reinforce this cooperation by achieving a purpose not otherwise attainable. The reciprocity which is a necessary feature of such a co-ordination of activity excludes the type of injustice that can be embodied in explicit rules. In fact, the sense of justice which emerges from these initial conventions can serve as a basis for assessing the justice of positive laws of property.

A final comment: We can imagine the oarsmen in Hume's analogy to be rowing a lifeboat away from others, whose lack of strength or the good fortune to have been situated near a boat leaves them out of any co-operative network. Should we not say that, at least where it would not be futile, the failure to co-operate would itself be a form of injustice. This type of problem did not escape Hume's notice. ${ }^{21}$ But he bites this bullet. The exclusion of those who are powerless shows a failure of humanity but not of justice. My own view is that Hume could extend his view to account for the supposition that the exclusion of the powerless is itself unjust. But I shall not take up that question here.

NATHAN BRETT

Dalhousie University

\section{NOTES}

1. J. Harrison, Hume's Theory of Justice, (Oxford, 1981) p. 30.

2. J. Rawls, A Theory of Justice, (Harvard, 1971) pp. 127-8.

3. Hume, A Treatise of Human Nature (Selby-Bigge ed., 1888) Bk. III, Pt. II.

4. Hume, Enquiries Concerning The Human Understanding and The Principles of Morals (Selby-Bigge ed., 1902) Section III, and Appendix III. Henceforth, I shall use $T$ and $E$ to refer to these editions of the Treatise and Enquiries.

5. T, pp. 515; E, pp. 197-99.

6. A difficulty could be raised here. Given what we now generally believe about the territoriality of various animals, do we have evidence that property 
distinctions are a natural, instinctual, response to objects in our environment? Hume could admit that there is a natural tendency to establish property (or property-like) distinctions while holding that these distinctions are themselves artificial in the sense that they have a basis in convention. Further, he could argue that animals, too, establish conventional relationships between themselves and objects. Hume did not endorse the sharp division between animals and human beings characteristic of his predecessors (including Locke). When it turns out that on his account animals could engage in causal reasoning, Hume embraces this as further evidence that his view of causation is correct. A similar point can be made regarding the analyses of pride and humility ( $T$, pp. 324-8), and of malice, envy, and sympathy (T. p. 395-97) -- all of which Hume claims to discover in rudimentary forms in non-human animals. He does say in passing that animals are "incapable of right and property" ( $T$, p. 396); but if territorial behaviour and (hence attitudes) proved to be comparable to our attitudes toward property, there is no reason why he should not revise this view. Conventions governing property are not initially explicit, so property distinctions cannot be denied to animals on the basis of their supposed lack of language.

7. Locke, The Second Treatise of Government, Ch. V, especially S. 27. Hume's criticisms of Locke's theory of acquisition are contained in the footnote at $T$, pp. 505-6.

8. "[T] $]$ here is first a natural union between the idea of a person and that of the object and afterwards a new and moral union produced by that right or property, which we ascribe to the person" $(T, 510 \mathrm{n})$.

9. The example of the madman who requests the return of a knife previously borrowed from him (in Bk. I of The Republic).

10. See, e.g., E, p.189n.

11. See L. M. Lacoste, "The Consistency of Hume's Position Concerning Women," 15 Dialogue (1976) pp. 425-40, and S. Burns, The Humean Female, 15 Dialogue, pp. 415-24.

12. Second Treatise, S. 27.

13. Here I am oversimplifying. Both Locke and Hume hold that property can exist independently of civil law, i.e., in a Lockean state of nature. But for Locke this is because there are natural rights to property. Hume, on the other hand, holds that there could be (and must have been) conventions establishing property prior to the introduction of positive law.

14. "Those, therefore, who make use of the words property, right, or obligation, before they have explained the origin of justice, or even make use of them in their explication, are guilty of a very gross fallacy ..." (T, p. 491).

15. Again I find myself consulting the dictionary in search of a connection in the language which both Locke and Hume were relying upon. It is interesting to discover that 'property' and 'propriety' were interchangeable, and derived from the same root. The latter certainly suggests a connection with convention which is not as obvious in 'property'. But still the supposed connection with justice remains as opaque as before. 
16. Here I am treating distributive justice as the basic concept from which rectificatory and even retributive justice are derived. I will not defend this assumption here.

17. See E, pp. 193-4.

18. Hume discusses this aspect of jurisprudence in a lengthy footnote running from $T$, pp. 505 to 508 .

19. See $T$, pp. 488-9, where Hume discusses the need for rules of justice in overcoming the "partial and unequal affection" which is natural to us.

20. The example is repeated in the Enquiry (Appendix, pp. 306-7). In both works a comparison is also made with the conventions which establish money and which give meanings to words. An excellent discussion of convention is $P$. Ardal, "Convention and Value," in David Hume: Bicentenary Papers, (Edinburgh, 1977) pp. 51-67.

21. Hume argues that if we were to interact with creatures of "inferior strength ... we should be bound by the law of humanity to give gentle usage to these creatures, but should not, properly speaking lie under any restraint of justice with regard to them" (E, p. 190). Such a relationship, he goes on to say, has sometimes existed between men and women. But the possibility that injustice may be involved after all is suggested by his reference to this subservience of women as "tyranny" ( $E$, p. 191). 